\title{
Effect of soil media on the rooting of Myrtus communes and Berberis thunbergii semi -hardwood cuttings
}

\author{
Sawsan Mohammed -saeed Ali Kanimarani \\ Department of Forestry and Horticulture, College of Agriculture,University of Salahaddin, Erbil, Kurdistan \\ Region, Iraq
}

\begin{abstract}
Two different compots (soil conditioner Latvia compost and local composts) in different proportions with river sand were used for rooting of two ornamental shrubs) Berberis thunbergii and Myrtus communes semi-hardwood cuttings, which were taken in 16-3-2011. Sand medium shows the most effective treatment in both plants. However the interaction of Myrtus communes cuttings and the control of soil conditioner Latvia compost gave the highest rooting percentage (50\%). The highest number of roots $(9.00)$ was counted from the interaction of Berberis thunbergii with (4:2) proportions of soil conditioner compost and sand. However the longest root, number of shoots and the highest number of leaves $(13.80 \mathrm{~cm}), 5.16$ and 25.44 respectively) were recorded from Berberis thunbergii cuttings in the sand medium. Longest shoot $(1.60 \mathrm{~cm})$ was obtained from Myrtus communes cuttings when cultivated in soil conditioner compost. The largest number of leaves (25.44) was counted from Berberis thunbergii cuttings when cultivated in the control of local compost, with no significant differences with the control of soil conditioner compost for the same species.
\end{abstract}

Key word: Berberis thunbergii, Myrtus communes, semi-hardwood cuttings, Latvia and local compost.

\section{Introduction}

Myrtus communes or true Myrtle (Myrtaceae family) is an evergreen shrub, small tree with dense foliage, the 2 inch lanceolate leaves are strongly scented when crushed, has $3 / 4$ inch white flowers sweetly scented, bloom in summer, and the plant is highly drought tolerant (Katzer, 2001).

Berberry family, Berberidaceae includes about 10 genera and 300 wide-spread species, mainly in north temperate regions (Novak, 1974). Berberis thunbergii is deciduous shrub, 2- $4 \frac{1}{2} \mathrm{~m}$ tall, ovate, simple and entire leaves, small yellowish flowers, bloom in may in clusters of 2- 4 flowers, drupe fruits turning red in summer (Gygan, 2011). Berberis are generally propagated by cuttings, semi -hardwood cuttings taken from spring to fall seasone (Murphree et al, 2000).

Myrtus communes and Berberis thunbergii are a popular woody ornamental shrubs utilized by the land scape industry as accent plants, hedges, or foundation planting (Palanisamy et al,1998). The crucial point for the exploitation Mediterranean species for agronomic purpose relies on the availability of planting material with high physiological quality. Vegetative propagation has unquestionable advantage for the propagator because it allows obtaining plants that reproduce exactly the genetic and morphological characteristics of the mother plant and, theoretically, it allow obtaining a large number of individuals in a short time. Among the various types of asexual propagation finds the greater application as it is technically easier to run and economically profitable in respect to all possible alternative methods (Melis, 2010).

Differences in root ability of cuttings are due to anatomical, physiological, biochemical and environmental factors. The physiological processes of root initiation are very complex and are influenced by many factors. No single factor but a specific constellation between them determines the rooting ability of cuttings. The most important factors that can affect the rooting potential of stem cuttings of more ornamental shrubs are the timing or date of cutting collection and the types of the cutting (Chjnowska, 2004).

The rooting media have great effect on the rooting ability of stem cuttings of most ornamental plants, such as mixture of peat and perilite at different portions were tested for rooting of two species of Sorbus, apaittosporum tobira, and white cedar cuttings (Hansen, 1990; Wang, 1991 and Hinesley et al, 1994 respectively). Medium of high light Baltic peat (coming from Latvia) containing $0.4 \%$ nitrogen, mixed with addition of coconut fiber were used for rooting of pelargonium cuttings (Zalewska and Wozny, 2004). In the other hand nitrogen deficiency raised starch levels in pelargonium cuttings, whereas the concentration of glucose and total sugar in the leaves and the basal stem were positively correlated with internal total nitrogen (Druege et al, 2004). The effect of cutting rooting media were studied in wide range, a mixture of peat and crushed plastic loam and a mixture of peat and perlite (1:1, v: v) each for rooting of olive stem cuttings ( Wiesman and Lavee, 1995) and on rooting of peach cuttings ( Gur et al, 1989) respectively. River sand alone or with silt (1:1, v: v) were used for rooting of Shorea leprosula (Aminah et al, 1995) and for rooting of four apple cultivars (Kanymarany and Abdul, 2009) respectively. 
The purpose of the present study was to determine the usefulness of soil conditioner Latvia compost compared with local compost as elements of rooting media of Berberis thunbergii and Myrtus communes semi hardwood cuttings.

\section{Material and methods}

A plastic house experiment was carried out in engineering parks nursery in Erbil with Berberis thunbergii and Myrtus communes semi -hardwood cuttings of $15 \mathrm{~cm}$ in length (Murphree et al, 2000), which were planted in different rooting media. The parent plant materials were grown in the same nursery; the cuttings were collected and planted in the morning of 16-3-2011 and harvested after three months. Air temperature and relative humidity were recorded and shown in table 1.

Eight different propagation media were prepared from river sand with Latvia soil conditioner compost and local compost (from agriculture research center in Erbil) in different portions (0-6, 2-4, 4-2 and 6-0) for each. Some properties of these two composts were shown in table 2.

Plastic pots with $15 \mathrm{~cm}$ in diameter and height were filled with propagation media, before planting the bases of the cuttings were treated with fungal herbicide Raxel (Amin and Sakri, 2009).

After harvesting the data recorded on: rooting percentage, number of roots per cutting, longest root $(\mathrm{cm})$, number of shoots per cutting, longest shoot $(\mathrm{cm})$ and number of leaves per cutting.

The experiment was carried out as factorial completely randomized design with sixteen treatments each has four replications, each replication has six cuttings. The data were submitted to analysis of variance (F test) and the means compared by using least significant differences test (L S D) at the 5\% probability level (Al - Rawi and Khalaf -Allah, 1980). Static graph for windows system was used for all statistical analyses (Statigraphic version4.0, 1999).

\section{1- Effect of plant species}

\section{Results and discussion}

No significant differences were recording in the cutting of both species on rooting percentage, number of roots per cutting and longest shoot. However, significant differences were recorded on longest root, number of shoots and leaves per cutting, the highest values $(6.58 \mathrm{~cm}, 2.79$ and 14.64 respectively) were obtained in Berberis thunbergii cuttings (table 3). Before onset of leaf fall the deciduous woody plants generally accumulate nutrients in the shoots which are subsequently utilized for emergence of new sprouts (Palanisamy et al, 1998).

\section{2- Effect of the type of rooting media}

Rooting promotion did not correspond with the type of rooting media, no significant differences were observed in rooting percentage, number of roots, longest root, number of shoots and leaves. The promotive effect of the type of rooting media has been observed in longest shoot, the higher significant value $(0.90 \mathrm{~cm}) \mathrm{was}$ recorded for Latvia soil conditioner compost (table 4).

\section{3-Effect of rooting media proportions}

The cuttings show good significant response to rooting media proportions in all rooting and shoot characteristics. The highest values of rooting percentage, number of roots, longest root, number of shoots, longest shoot and number of leaves $(40.28 \%, 3.87,8.53 \mathrm{~cm}, 3.61,1.02 \mathrm{~cm}$ and 18.37 respectively) were recorded from sandy medium, and there are a great differences with other media (table 5).

\section{4- Interaction effects of the species and the type of rooting media}

Table (6) shows the interaction effects between the species and the type of rooting media. Significant differences were obtained in longest root, number of shoots, longest shoot and number of leaves. The highest values $(8.26 \mathrm{~cm}, 2.94,0.97 \mathrm{~cm}$ and 15.54 respectively) were recorded from the interaction between Berberis thunbergii cuttings and Latvia soil conditioner The lowest number of roots and longest root $(1.03$ and $1.16 \mathrm{~cm}$ respectively)were measured from the interaction between Myrtus communes cuttings and local compost, but the lowest number of shoots and leaves (1.42 and 7.29 respectively) were counted from the interaction between Myrtus communes cuttings and Latvia soil conditioner compost. However the lowest value of longest shoot $(0.47 \mathrm{~cm})$ was measured from the interaction between Berberis thunbergii cuttings and local compost. The supplementary nutrients improve root development after root primordia initiation has occurred. Hence propagation turnover occurs more quickly and plant growth is maintained by producing rooted liners that are more nutritionally fit. Optimum levels of fertilization for rooting need to be determined on a species base (Hartmann et al, 1990). 


\section{5- Interaction effects of the species and rooting media proportions}

Interaction between species and rooting media proportions showed significant effects for all rooting and shoot characteristics (table 7$)$. The highest rooting percentage and longest shoot $(47.22 \%$ and $1.10 \mathrm{~cm}$ respectively) were recorded from Myrtus communes cuttings when cultivated in the sand. However the highest number of roots, longest root, number of shoots and leaves $(4.94,14.20 \mathrm{~cm}, 4.56$ and 24.81 respectively) were observed from Berberis thunbergii cuttings when cultivated in the sand too. The results indicated clearly that the rooting potential was not sensitive for the variation of the rooting media proportions, because the sandy medium is more effective than others for both species generally. These results may be due to the porosity of the sandy medium which is critical for enabling the diffusion of oxygen to the cutting bases, and for a good penetration of adventitious root.

\section{6- Interaction effects of the type of rooting media and proportions}

Rooting ability of the cuttings depended on the interaction between the type of rooting media and their proportions affected significantly on the rooting ability of the cuttings (table 8). The highest values for rooting percentage and number of roots $(41.67 \%$ and 4.05 respectively) were recorded from control treatment of Latvia soil conditioner compost. However the highest longest roots, number of shoots and leaves $9.00 \mathrm{~cm}, 3.67$ and 19.66 respectively) were obtained from the control of the local compost, and the longest shoot $(1.28 \mathrm{~cm})$ were measured from 6:0 Latvia soil conditioner compost.

\section{7- Interaction effects of the species, type of rooting media and proportions}

Interaction of the species, type of rooting media and proportions affected significant differences on rooting and shoot characteristics (table 9). It was recorded that Myrtus communes cuttings gave highest rooting percentage when were cultivated in sandy soil (50\% and $44.44 \%$ with no significant differences) in both Latvia soil conditioner and local compost respectively. The highest number of roots (9.00) was counted from Berberis thunbergii cuttings when cultivated in 4-2 proportion of Latvia soil conditioner compost. While the highest values of longest root and number of shoots $(13.80 \mathrm{~cm}$, and 5.16) were obtained from the Berberis thunbergii cuttings when cultivated in the control of Latvia soil conditioner compost, but the highest value of longest shoot $(1.60 \mathrm{~cm})$ were recorded from Myrtus communes cuttings when cultivated in 6:0 proportion of Latvia soil conditioner compost. The largest number of leaves (25.44) was counted from Berberis thunbergii cuttings when cultivated in the control of local compost, with no significant differences with the control of soil conditioner compost for the same species. Both composts were lead to falling in rooting ability and other characteristics, these results may be due to the high capacity of these two composts to held water and caused decaying of cutting bases.

This study showed that the sandy soil medium was most effective and there were grate variations between the sand and the other proportions of both composts in most studied characteristics. Otherwise, Latvia soil conditioner compost was more effective than local compost especially on the Berberis thunbergii cuttings.

Table (1): Maximum and minimum air temperatures and humidity throughout the experiments period.

\begin{tabular}{|c|c|c|c|c|c|}
\hline \multirow[b]{2}{*}{ Year } & \multirow[b]{2}{*}{ Month } & \multicolumn{2}{|c|}{ Air temperature $\mathrm{C}^{\mathbf{0}}$} & \multicolumn{2}{|c|}{ Relative humidity\% } \\
\hline & & maximum & minimum & maximum & minimum \\
\hline \multirow{4}{*}{2011} & March & 18.9 & 9.0 & 80.2 & 52.5 \\
\hline & April & 23.9 & 14.9 & 73.6 & 46.0 \\
\hline & May & 30.2 & 19.7 & 61.2 & 31.6 \\
\hline & June & 37.6 & 25.7 & 49.6 & 30.1 \\
\hline
\end{tabular}

Table (2): Some properties of the two composts used in the experiments.

\begin{tabular}{|c|c|c|}
\hline \multirow{2}{*}{ Properties } & $\begin{array}{c}\text { soil conditioner } \\
\text { compost }\end{array}$ & $\begin{array}{c}\text { local } \\
\text { compost }\end{array}$ \\
\hline $\mathrm{N} \%$ & 0.89 & 1.52 \\
\hline $\mathrm{P} \%$ & 0.02 & 0.42 \\
\hline $\mathrm{K} \%$ & 0.10 & 0.55 \\
\hline $\mathrm{pH}(\mathrm{pH}-\mathrm{meter})$ & 3.65 & 8.3 \\
\hline $\begin{array}{c}\text { Electric conductivity } \\
\left(\text { ds. } \text { m }^{-1}\right)\end{array}$ & 0.25 & 2.03 \\
\hline
\end{tabular}

Table (3): Effect of plant species on rooting and shoot characteristics. 
Effect of soil media on the rooting of Myrtus communes and Berberis thunbergii semi-hardwood

\begin{tabular}{|c|c|c|c|c|c|c|}
\hline species & $\begin{array}{c}\text { Rooting } \\
\text { percentage }\end{array}$ & $\begin{array}{c}\text { Number of } \\
\text { roots/ } \\
\text { cutting }\end{array}$ & $\begin{array}{c}\text { Longest } \\
\text { root } \\
\text { (cm) }\end{array}$ & $\begin{array}{c}\text { Number } \\
\text { of } \\
\text { shoots/ } \\
\text { cutting }\end{array}$ & $\begin{array}{c}\text { Longest } \\
\text { shoot } \\
(\mathrm{cm})\end{array}$ & $\begin{array}{c}\text { Number } \\
\text { of } \\
\text { leaves/ } \\
\text { cutting }\end{array}$ \\
\hline $\begin{array}{c}\text { Berberes } \\
\text { thunbergii }\end{array}$ & 14.65 & 2.80 & 6.58 & 2.79 & 0.71 & 14.64 \\
\hline $\begin{array}{c}\text { Myrtus } \\
\text { communs }\end{array}$ & 14.58 & 1.24 & 1.32 & 1.58 & 0.67 & 7.73 \\
\hline L.S.D. $<0.05$ & N.S. & N.S. & $\mathbf{2 . 1 0}$ & $\mathbf{0 . 7 6}$ & N.S. & 2.84 \\
\hline
\end{tabular}

Table(4): Effect of rooting medium types on rooting and shoot characteristics.

\begin{tabular}{|c|c|c|c|c|c|c|}
\hline rooting medium types & $\begin{array}{c}\text { Rooting } \\
\text { percentage }\end{array}$ & $\begin{array}{c}\text { Number of } \\
\text { roots/ } \\
\text { cutting }\end{array}$ & $\begin{array}{c}\text { Longest } \\
\text { root } \\
\text { (cm) }\end{array}$ & $\begin{array}{c}\text { Number of } \\
\text { shoots/ } \\
\text { cutting }\end{array}$ & $\begin{array}{c}\text { Longest } \\
\text { shoot } \\
(\mathbf{c m})\end{array}$ & $\begin{array}{c}\text { Number of } \\
\text { leaves/ } \\
\text { cutting }\end{array}$ \\
\hline $\begin{array}{c}\text { Latvia soil conditioner } \\
\text { compost }\end{array}$ & 17.08 & 2.24 & 4.87 & 2.18 & 0.90 & 11.42 \\
\hline local compost & 12.15 & 1.80 & 3.03 & 2.19 & 0.48 & 10.96 \\
\hline L.S.D.<0.05 & N.S. & N.S. & N.S. & N.S. & 0.29 & N.S. \\
\hline
\end{tabular}

Table (5): Effect of rooting medium levels on rooting and shoot characteristics.

\begin{tabular}{|c|c|c|c|c|c|c|}
\hline $\begin{array}{c}\text { Medium } \\
\text { levels* }\end{array}$ & $\begin{array}{c}\text { Rooting } \\
\text { percentage }\end{array}$ & $\begin{array}{c}\text { Number of } \\
\text { roots/ } \\
\text { cutting }\end{array}$ & $\begin{array}{c}\text { Longest } \\
\text { root } \\
\text { (cm) }\end{array}$ & $\begin{array}{c}\text { Number } \\
\text { of } \\
\text { shoots/ } \\
\text { cutting }\end{array}$ & $\begin{array}{c}\text { Longest } \\
\text { shoot } \\
\text { (cm) }\end{array}$ & $\begin{array}{c}\text { Number of } \\
\text { leaves/ } \\
\text { cutting }\end{array}$ \\
\hline $0: 6$ & 40.28 & 3.87 & 8.53 & 3.61 & 1.02 & 18.37 \\
\hline $2: 4$ & 4.86 & 1.58 & 1.58 & 1.42 & 0.34 & 6.29 \\
\hline $4: 2$ & 5.56 & 1.58 & 2.02 & 2.71 & 0.77 & 14.28 \\
\hline $6: 0$ & 7.78 & 1.04 & 3.83 & 1.01 & 0.64 & 5.81 \\
\hline L.S.D.<0.05 & 10.48 & 2.22 & 2.97 & 1.08 & 0.41 & 4.02 \\
\hline
\end{tabular}

$* 0: 6=$ only sand,

$2: 4=2$ is soil conditioner (or local compost) and 4 is sand, $4: 2=4$ is soil conditioner (or local compost) and 2 is sand, 6:0 $=$ only soil conditioner (or local compost).

Table (6): Interaction effects of plant species and rooting media types on rooting and shoot characteristics.

\begin{tabular}{|c|c|c|c|c|c|c|c|}
\hline species & $\begin{array}{c}\text { rooting medium } \\
\text { types }\end{array}$ & $\begin{array}{c}\text { Rooting } \\
\text { percentage }\end{array}$ & $\begin{array}{c}\text { Number of } \\
\text { roots/ } \\
\text { cutting }\end{array}$ & $\begin{array}{c}\begin{array}{c}\text { Longest } \\
\text { root }\end{array} \\
(\mathrm{cm})\end{array}$ & $\begin{array}{c}\text { Number of } \\
\text { shoots/ } \\
\text { cutting }\end{array}$ & $\begin{array}{c}\text { Longest } \\
\text { shoot } \\
(\mathrm{cm})\end{array}$ & $\begin{array}{c}\begin{array}{c}\text { Number } \\
\text { of } \\
\text { leaves/ } \\
\text { cutting }\end{array}\end{array}$ \\
\hline \multirow{2}{*}{$\begin{array}{l}\text { Berberes } \\
\text { thunbergii }\end{array}$} & $\begin{array}{c}\text { Latvia soil } \\
\text { conditioner } \\
\text { compost }\end{array}$ & 17.50 & 3.03 & 8.26 & 2.94 & 0.97 & 15.54 \\
\hline & local compost & 11.81 & 2.57 & 4.89 & 2.64 & 0.47 & 13.74 \\
\hline \multirow{2}{*}{$\begin{array}{l}\text { Myrtus } \\
\text { communs }\end{array}$} & $\begin{array}{c}\text { Latvia soil } \\
\text { conditioner } \\
\text { compost }\end{array}$ & 16.67 & 1.46 & 1.48 & 1.42 & 0.83 & 7.29 \\
\hline & local compost & 12.5 & 1.03 & 1.16 & 1.75 & 0.50 & 8.18 \\
\hline \multicolumn{2}{|c|}{ L.S.D. $<0.05$} & N.S. & N.S. & 2.98 & 1.08 & 0.41 & 4.03 \\
\hline
\end{tabular}


Table (7): Interaction effects of plant species and rooting media levels on rooting and shoot characteristics.

\begin{tabular}{|c|c|c|c|c|c|c|c|}
\hline species & $\begin{array}{l}\text { Medium } \\
\text { levels }\end{array}$ & $\begin{array}{c}\text { Rooting } \\
\text { percentage }\end{array}$ & $\begin{array}{c}\text { Number } \\
\text { of } \\
\text { roots/ } \\
\text { cutting }\end{array}$ & $\begin{array}{l}\text { Longest } \\
\text { root } \\
\text { (cm) }\end{array}$ & $\begin{array}{c}\text { Number of } \\
\text { shoots/ } \\
\text { cutting }\end{array}$ & $\begin{array}{l}\text { Longest } \\
\text { shoot } \\
(\mathrm{cm})\end{array}$ & $\begin{array}{c}\text { Number of } \\
\text { leaves/ } \\
\text { cutting }\end{array}$ \\
\hline \multirow{4}{*}{$\begin{array}{c}\text { Berberes } \\
\text { thunbergii }\end{array}$} & 0:6 & 33.33 & 4.94 & 14.20 & 4.56 & 0.93 & 24.81 \\
\hline & $2: 4$ & 9.72 & 3.17 & 3.17 & 2.83 & 0.68 & 12.58 \\
\hline & $4: 2$ & 2.78 & 1.50 & 2.07 & 2.36 & 0.57 & 12.33 \\
\hline & $6: 0$ & 12.78 & 1.58 & 6.87 & 1.42 & 0.68 & 8.83 \\
\hline \multirow{4}{*}{$\begin{array}{l}\text { Myrtus } \\
\text { communs }\end{array}$} & $0: 6$ & 47.22 & 2.80 & 2.50 & 2.67 & 1.10 & 11.93 \\
\hline & $2: 4$ & 0.00 & 0.00 & 0.00 & 0.00 & 0.00 & 0.00 \\
\hline & $4: 2$ & 8.34 & 1.67 & 1.97 & 3.06 & 0.97 & 16.22 \\
\hline & $6: 0$ & 2.78 & 0.50 & 0.80 & 0.61 & 0.60 & 2.78 \\
\hline \multicolumn{2}{|c|}{ L.S.D. $<0.05$} & 14.86 & 3.44 & 4.21 & 1.53 & 0.58 & 5.70 \\
\hline
\end{tabular}

Table (8): Interaction effects of rooting medium types and levels on rooting and shoot characteristics.

\begin{tabular}{|c|c|c|c|c|c|c|c|}
\hline $\begin{array}{l}\text { composts } \\
\text { types }\end{array}$ & $\begin{array}{c}\text { Rooting } \\
\text { medium } \\
\text { levels }\end{array}$ & $\begin{array}{c}\text { Rooting } \\
\text { percentage }\end{array}$ & $\begin{array}{c}\text { Number of } \\
\text { roots/ } \\
\text { cutting }\end{array}$ & $\begin{array}{l}\text { Longest } \\
\text { root } \\
\text { (cm) }\end{array}$ & $\begin{array}{l}\text { Number } \\
\text { of } \\
\text { shoots/ } \\
\text { cutting }\end{array}$ & $\begin{array}{c}\text { Longest } \\
\text { shoot } \\
\text { (cm) }\end{array}$ & $\begin{array}{c}\text { Number of } \\
\text { leaves/ } \\
\text { cutting }\end{array}$ \\
\hline \multirow{4}{*}{$\begin{array}{l}\text { Latvia soil } \\
\text { conditioner } \\
\text { compost }\end{array}$} & 0:6 & 41.67 & 4.05 & 7.7 & 3.56 & 1.18 & 17.08 \\
\hline & $2: 4$ & 2.78 & 0.50 & 0.68 & 1.00 & 0.33 & 3.83 \\
\hline & $4: 2$ & 8.33 & 2.33 & 3.42 & 2.14 & 0.80 & 13.14 \\
\hline & $6: 0$ & 15.56 & 2.08 & 7.67 & 2.03 & 1.28 & 11.61 \\
\hline \multirow{4}{*}{ local compost } & $0: 6$ & 38.89 & 3.69 & 9.00 & 3.67 & 0.85 & 19.66 \\
\hline & $2: 4$ & 6.95 & 2.67 & 2.48 & 1.83 & 0.35 & 8.75 \\
\hline & $4: 2$ & 2.78 & 0.83 & 0.62 & 3.28 & 0.73 & 15.42 \\
\hline & $6: 0$ & 0.00 & 0.00 & 0.00 & 0.00 & 0.00 & 0.00 \\
\hline \multicolumn{2}{|c|}{ L.S.D. $<0.05$} & 14.86 & 3.44 & 4.21 & 1.53 & 0.58 & 5.70 \\
\hline
\end{tabular}

Table (9): Interaction effects of plant species, rooting media types and levels on rooting and shoot characteristics.

\begin{tabular}{|c|c|c|c|c|c|c|c|c|}
\hline species & composts types & $\begin{array}{c}\text { Rooting } \\
\text { medium } \\
\text { levels }\end{array}$ & $\begin{array}{c}\text { Rooting } \\
\text { percentage }\end{array}$ & $\begin{array}{c}\text { Number } \\
\text { of } \\
\text { roots/ } \\
\text { cutting }\end{array}$ & $\begin{array}{l}\text { Longest } \\
\text { root } \\
\text { (cm) }\end{array}$ & $\begin{array}{c}\text { Number } \\
\text { of } \\
\text { shoots/ } \\
\text { cutting }\end{array}$ & $\begin{array}{c}\text { Longest } \\
\text { shoot } \\
(\mathrm{cm})\end{array}$ & $\begin{array}{c}\text { Number of } \\
\text { leaves/ } \\
\text { cutting }\end{array}$ \\
\hline \multirow{8}{*}{$\begin{array}{c}\text { Berberes } \\
\text { thunbergii }\end{array}$} & \multirow{4}{*}{$\begin{array}{c}\text { Latvia soil } \\
\text { conditioner } \\
\text { compost }\end{array}$} & $0: 6$ & 33.33 & 4.94 & 13.80 & 5.16 & 1.20 & 24.17 \\
\hline & & $2: 4$ & 5.56 & 3.00 & 4.10 & 3.00 & 1.00 & 11.50 \\
\hline & & $4: 2$ & 5.56 & 9.00 & 12.40 & 2.00 & 0.63 & 12.67 \\
\hline & & $6: 0$ & 25.56 & 31.67 & 13.73 & 2.82 & 1.37 & 17.67 \\
\hline & \multirow{4}{*}{ local compost } & $0: 6$ & 33.33 & 4.94 & 11.27 & 4.00 & 0.67 & 25.44 \\
\hline & & $2: 4$ & 13.89 & 3.00 & 7.45 & 3.67 & 0.7 & 17.50 \\
\hline & & $4: 2$ & 0.00 & 0.00 & 0.00 & 2.89 & 1.5 & 12.00 \\
\hline & & $6: 0$ & 0.00 & 0.00 & 0.00 & 0.00 & 0.00 & 0.00 \\
\hline \multirow{8}{*}{$\begin{array}{l}\text { Myrtus } \\
\text { communs }\end{array}$} & \multirow{4}{*}{$\begin{array}{l}\text { Latvia soil } \\
\text { conditioner } \\
\text { compost }\end{array}$} & $0: 6$ & 50.00 & 3.16 & 6.4 & 2.00 & 1.17 & 10.00 \\
\hline & & $2: 4$ & 0.00 & 0.00 & 0.00 & 0.00 & 0.00 & 0.00 \\
\hline & & $4: 2$ & 11.11 & 2.50 & 4.05 & 2.45 & 0.83 & 13.16 \\
\hline & & $6: 0$ & 15.66 & 3.00 & 4.80 & 1.67 & 1.60 & 4.62 \\
\hline & \multirow{4}{*}{ local compost } & $0: 6$ & 44.44 & 2.28 & 3.4 & 3.33 & 1.03 & 13.87 \\
\hline & & $2: 4$ & 0.00 & 0.00 & 0.00 & 0.00 & 0.00 & 0.00 \\
\hline & & $4: 2$ & 5.56 & 5.00 & 3.70 & 3.67 & 0.97 & 18.83 \\
\hline & & $6: 0$ & 0.00 & 0.00 & 0.00 & 0.00 & 0.00 & 0.00 \\
\hline \multicolumn{3}{|c|}{ L.S.D. $<0.05$} & 21.02 & 4.45 & 5.96 & 2.16 & 0.82 & 8.06 \\
\hline
\end{tabular}




\section{References}

[1] Al-Rawi, K. M. and A. M. Khalaf-Allah (1980). Design and Analysis of Agriculture Experiment. Mosul University Press

[2] Amin, S. A. and F. A. Sakri (2009). Effect of salt stress on some chemical changes of four barle (Hordeum vulgare L.) cultivars. Zanco J. of Applied Science -Salahaddin University Hawler. 21(5):63 - 74.

[3] Aminah, H.; J. M. Dick; R.R.B. Leakey; J. Grace and R. I. Smith (1995). Effect of indole butyric acid(IBA) on stem cuttings of Shorea leprosula .Forest Ecology and Management 72:199-206.

[4] Chojnowska, E. (2004). The effect of cutting dates, temperature and different rooting stimulators on the rooting of cuttings of Aubrieta cultorum. Electronic J. of Polish Agriculture Universities, Horticulture, 7(2).

[5] Druege, U.; S. Z.erche and R. Kdner (2004). Nitrogen -and storage -affected carbohydrate partitioning in high -light adapted pelargonium cuttings in relation to survival and adventitious root formation under low light. Annals of Botany. http.//aob.oxfordjournals.org./cgi /content/ full/94/6/831

[6] Gur,A.; A. Altman; R. Stern and B. Wolowitz (1986). Improving rooting and survival of softwood peach cutting. Scientia Horticulturae, 30: 97-108.

[7] Gygan, D. (2011). New Hampshire guide to upland Invasive species $3^{\text {rd }}$ edithion. New Hampshire department of agriculture markets and food, plant industry division.

[8] Hansen, O .(1990). Propagating Sorbus aucuparia L. and Sorbus hybrid L. bysoftwood cuttings. Scientia Horticulturae. 42 :169 175 .

[9] Hartmann, H.; D. E. Kester and F. T. Davies (1990). Plant propagation principles and practices. $5^{\text {th }}$ edition. Hall international, Inc. New Jersey, USA.

[10] Hinesley, E.; F. A. Blazich and L. k. Snelling (1994). Propagatoion of Atlantic white cedar by stem cutting. Hort. Science 29(3):217 $-219$.

[11] Kanymarany, S. M.-S. A. and Abdul (2009). Effect of stockplant locations on rooting ability of different apple cultivars. Zanco. J. of applied scinces/ Salahaddin University- Hawler. 21(5):117-122.

[12] Katzer, G.(2001). Myrtus communis (free myrtul) Myrtaceae. D://clas.arizona.edu/pima/gardenina/aridplants /Myrtus communis.html

[13] Melis, R. A. M. (2010). Influence of environmental and cultural factors on structure composition and aganic propagation of two Mediterranean shrubs (Myrtus communis L. - Pistacia lentiseus L.) titoli, abstracts, parole chiave -universita' degli studi di Sassari.

[14] Murphree, B. H.; J. L. Sibley; D. J. Eakes and J. D. Williams (2000). Shade influence propagation of golden barberry (Bailsel). Horttechnology, 10(4):752- 753 .

[15] Novak, F. A. (1974). The pictorial encyclopedia of plant and flowers. The hamlyn publishing group limited.

[16] Plalnisamy, S. A., S. A. Ansari; p. Kumar and B.N. Gupta (1998). Adventitious rooting in shoot cuttings of Azadirachta indica and Pongamia pinnata. New forest 16:81-88.

[17] Statigraphics version 4.0, Http://WWW.Statgraphics.Com, Accessed $15-2-1999$.

[18] Wang, Y. T. (1991). Mist quality, rooting hormone collection time and medium effect on propagation of Pitosporum tobira (Thunb.) Ait. . J. Environ. Horticulture 9(4):199 - 203.

[19] Wiesman, Z. and S. Lavee (1995). Enhancement of IBAstimulatory effect on rooting of olive cultivar stem cuttings Scientia Horticulturae 62:189-198.

[20] Zalewska, M. and A. Wozny (2004). The effect of Coconut fibers on the rooting of border pelargonium (Pelargonnium hortorum L. H. Bailey) cuttings. Electronic J. of Polish Agriculture Universities, Horticulture, 7(2). 